\title{
Effect of Cerbera Manghas Biodiesel on Diesel Engine Performance
}

\author{
Willyanto Anggono ${ }^{1,2 *}$, M. M. Noor ${ }^{3}$, F. D. Suprianto ${ }^{1,2}$, L. A. Lesmana ${ }^{1,2}$, G. J. \\ Gotama $^{1,2}$, A. Setiyawan ${ }^{4}$ \\ ${ }^{1}$ Centre for Sustainable Energy Studies, Petra Christian University, \\ Surabaya 60236, Indonesia. \\ ${ }^{2}$ Mechanical Engineering Department, Petra Christian University, \\ Surabaya 60236, Indonesia. \\ ${ }^{3}$ Mechanical Engineering Department, Universiti Malaysia Pahang, \\ 26600, Pekan, Pahang, Malaysia. \\ ${ }^{4}$ Mechanical Engineering Department, Sepuluh Nopember Institute of Technology, \\ Surabaya 60111, Indonesia. \\ *Email: willy@petra.ac.id \\ Phone: +62312983472; Fax: +62318436418
}

\begin{abstract}
In order to reduce the use of fossil fuel without interfering the availability of food crop, Cerbera manghas biodiesel has been studied as potential renewable fuel. This study investigated Cerbera manghas biodiesel as a replacement for pure petro-diesel and palm oil biodiesel produced in Indonesia. The investigation result indicates that Cerbera manghas biodiesel fuel has a lower density, kinematic viscosity, sulfur content, color (lighter), water content, distillation point compared to pure petro-diesel and palm oil biodiesel. Higher flash point and cetane index value in Cerbera manghas biodiesel were also discovered. The study investigated further the effect of biodiesel derived from Cerbera manghas biodiesel compared with pure petro-diesel and palm oil biodiesel in a single cylinder diesel engine. The study suggested that Cerbera manghas biodiesel has better engine performance (fuel consumption, brake mean effective pressure, thermal efficiency, torque, and power) compared to pure petro-diesel and palm oil biodiesel. The utilization of Cerbera manghas biodiesel gave better engine performance output compared to pure petro-diesel and palm oil biodiesel. This study supported the viability of Cerbera manghas biodiesel to be implemented as an alternative diesel fuel without interfering food resources or requiring additional modification to the existing diesel engine.
\end{abstract}

Keywords: Sustainable energy; Cerbera manghas; biodiesel; engine performance; non-edible fuel.

\section{INTRODUCTION}

Energy is the main factor to increase the development of economy around the world. Even though non-renewable fuel is constrained in number, the need of non-renewable fuel is growing rapidly [1-4]. The depletion of fossil fuel and reduced environmental condition are considered to be the immense energy problem today [5]. To halt and minimize this problem, an alternative and renewable source of energy is required [6].

Biofuel is one of many solutions to be considered as an answer to solve fossil fuel reduction and environmental damages [6-9]. Biodiesel consists of alcohol attached 
to fatty acids with long-chain, often derived from biological sources [10,11]. Development of biodiesel or biofuel as an alternative energy source is well placed to address the problem because biodiesel is environmentally friendly and more biodegradable [3,12]. Biodiesel feedstock can be obtained in a simple way through the cultivation of biofuel crops and taking advantage of the existing waste around human life [13]. Most common method to obtain biodiesel is through transesterification [14]. Transesterification, which is a reversible reaction, is known as the most important method to obtain biodiesel [15]. The advantages of using biodiesel compared to Petroleum diesel are the renewable raw materials, high energy efficiency, low combustion engine emissions and easily utilized. The study of biodiesel will also benefit rural area since its raw materials are easily obtained [16].

Biofuel is also capable to be mixed at any level of percentage with common fuel. The result of the blend does not require additional upgrade or modification to the engine used [17]. Furthermore, biofuel can be blended with oil diesel and the mixing is not bounded in any extent. Biodiesel requires only small adjustment or no adjustment at all when used in internal combustion engine [17-19]. Biodiesel mixed with diesel will convey numerous valuable qualities to the diesel engine. From these information, it can be concluded how convenience is biodiesel for furthering the cause of renewable and sustainable energy study.

Albeit all those advantages of biodiesel and the high number of studies to investigate biodiesel from natural sources, biodiesel developments are criticized for reducing food supply. The most prominent reason for biodiesel production comes from the fact that enormous types of readily used feedstock for biodiesel and the abundant number of them [20]. Universally, it was found that more than 350 crops are able to be extracted for oil and biodiesel material [21-23]. Some of these crops are edible food crop and using them as biodiesel fuel are considered as wasting edible food resources. To avoid this issue arising further, some researcher found the versatility of biodiesel production which is able to be produced from non-edible materials. Some examples of such biodiesel are inedible animal tallow and shrubs [24, 25]. Non-food crop based vegetable oils are also viewed as viable sources of biodiesel fuel. Some examples of non-eatable vegetable feedstock are Calophyllumin ophyllum, Nicotiana tabacum, Hevea brasiliensis, Cerbera manghas and Jatropha curcas although most of them have high free unsaturated fat which requires pre-treatment handling before used as biofuel [26-28].

In Indonesia, the development of biodiesel is highly promising because Indonesia is a tropical country with untapped abundant natural resources. One of the plants that are often encountered in the community is Cerbera manghas. Cerbera manghas is a semi-mangrove plant which is common in tropical and subtropical location [29]. Cerbera manghas tree has dark green leaves with height ranging from 615 meters [30,31]. Cerbera manghas is known as one of the perennial plants that are widely used for greening, shading, decoration to the city and also as raw craft materials. Cerbera manghas grows in beachfront and brooks and in addition along the riverbanks. The seeds of Cerbera manghas consists of $54 \%$ Cerbera manghas oil (CCMO) [28,31]. The fatty acid components of CCMO are linoleic (17.8\%), oleic (48.1\%), palmitic $(30.3 \%)$, and stearic (3.8\%) [28]. All parts of the Cerbera manghas tree are inedible for consumption [30-33]. Since Cerbera manghas is not edible and thus not considered a food crop, Cerbera manghas will not compete with food needs when utilized as fuel. 


\section{EXPERIMENTAL SETUP}

The waste materials used in this study are the seeds from Cerbera manghas fruits. Fruits which have already fallen from the plant were cut open. The seeds were dried and crushed into the desired particle size $(60 \mathrm{Mesh})$ to ease the oil extraction process. Soxhlet apparatus was used to extract oil from Cerbera manghas seeds as shown in Figure 1 (a).

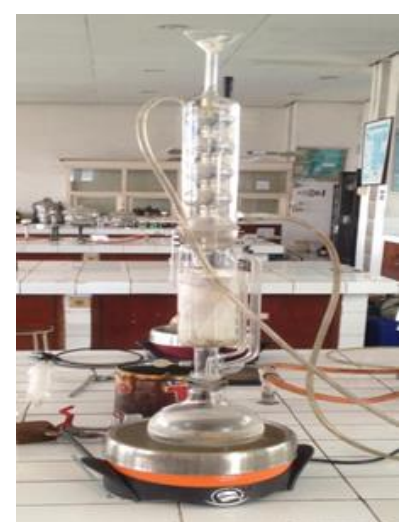

(a)

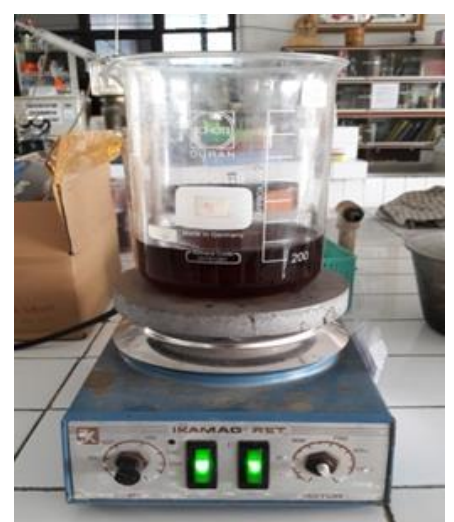

(b)

Figure 1. (a) Soxhlet and; (b) stirrer apparatus.

In this study, biodiesel derived from CCMO was compared with pure petrodiesel (PPD) and palm biodiesel (PBD) produced by fuel company in Indonesia. PPD is a pure petro-diesel and PBD is a mixture of petro-diesel with palm tree oil (Elaeis Guineensis), which is an edible vegetation. CCMO was blended with PPD in order to obtain 5\% biodiesel from CCMO in total PPD composition. In this paper, this blend was marked as Cerbera manghas biodiesel (CMB).

To determine CMB capability and fuel characteristics to be used as a diesel engine fuel, series of tests are carried together with PPD and PBD in order to understand the characteristics of CMB. The experimental investigation of Cerbera manghas biodiesel was examined using ASTM standard. The experiment was conducted in UPPS Pertamina (fuel company) laboratory Surabaya. The density was examined using ASTM D-1298. The kinematic viscosity was examined using ASTM D-445. The flash point was examined using ASTM D-93. The pour point was examined using ASTM D-97. The sulfur content was examined using ASTM D-4294. The color was examined using ASTM D-1500. The water content was examined using ASTM D6304. The cetane index was examined using ASTM D-4737. The distillation point was examined using ASTM D-86.

After determining the characteristics of CMB, PPD and PBD, an engine tests were performed on high speed single cylinder Yanmar TF55R diesel engine - Generator (Noqiwa) with additional equipment such as electrical load, measuring cup, stopwatch, pitot static tube, manometer $\mathrm{V}$, ammeters, voltmeter, digital thermometer, thermocouple, and digital tachometer. The electrical load consists of incandescent light bulbs by 10 pieces with power consumption of $200 \mathrm{~W}$ for each lamp. These lamps were arranged in parallel with each lamp equipped with a stop button/ contact for setting the load. Measuring cups were used to measure the amount of fuel consumed by a diesel engine. A stopwatch was used to measure the time required for the diesel engine to use diesel fuel as much as $10 \mathrm{ml}$. Pitot-Static Tube and Manometer V were used to measure 
the amount of fuel and air supplied to the combustion chamber. Ammeters, voltmeter, thermometer, thermocouple, and tachometer were used as measuring instruments to determine engine performance. The schematic diagram of experimental apparatus is shown in Figure 2, the electric generator specifications is shown in Table 1, and the engine specification is shown in Table 2.

Experimental apparatus shown in Figure 2 is indicated by uppercase alphabet letters. Uppercase alphabet A indicates the loading lamps component. Uppercase alphabet $\mathrm{B}$ indicates ammeters and voltmeters. Uppercase alphabet $\mathrm{C}$ indicates generator component as part of the engine. Uppercase alphabet D indicates measuring cup. Uppercase alphabet $\mathrm{E}$ indicates the engine. Uppercase alphabet $\mathrm{F}$ indicates manometer instrument.

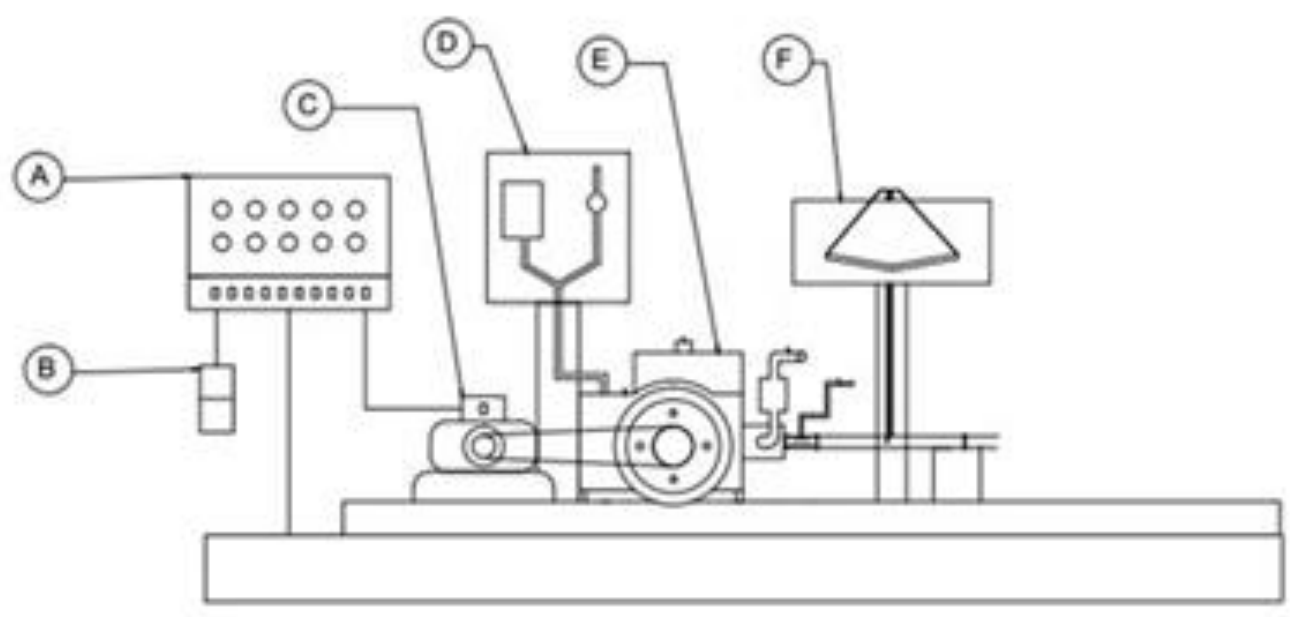

Figure 2. Schematic diagram of experimental apparatus.

Table 1 Electrical generator specifications.

\begin{tabular}{lc}
\hline Items & Description \\
\hline Brand & NOQIWA \\
Type & ST-3 \\
Power & $3 \mathrm{~kW}$ \\
Voltage $(\mathrm{V})$ & $220 \mathrm{Volt}$ \\
Current & $13,6 \mathrm{~A}$ \\
Frequency $(\mathrm{Hz})$ & $50 \mathrm{~Hz}$ \\
Rotation & $1500 \mathrm{rpm}$ \\
Cos $\varphi$ & 1 \\
Phase & 1 \\
Ev Volt (V) & 42 \\
Ex Curr (A) & 2 \\
\hline
\end{tabular}


Table 2 Engine specifications of high-speed single cylinder diesel engine.

\begin{tabular}{lc}
\hline Items & Description \\
\hline Brand & Yanmar \\
Model & TF55R \\
Working machines & 4 strokes, water cooler \\
Combustion system & direct injection \\
Cylinder & 1 cylinder \\
Injection timing & $17^{\circ}$ before TDC \\
Bore $\times$ stroke $(\mathrm{mm})$ & $75 \times 80$ \\
Cylinder volume $(\mathrm{cc})$ & 353 \\
Continuous power $(\mathrm{hp} / \mathrm{rpm})$ & $4,5 / 2200$ \\
Maximum power $(\mathrm{hp} / \mathrm{rpm})$ & $5,5 / 2200$ \\
Compression & $17,9: 1$ \\
Fuel pumps & Bosch \\
Injector pressure $\left(\mathrm{kg} / \mathrm{cm}{ }^{2}\right)$ & 200 \\
Lubrication system & Forced lubrication \\
Lubricating oil capacity $($ Liter $)$ & 1,8 \\
Fuel tank capacity $($ Liter $)$ & 7,1 \\
Lubrication oil & SAE 40 CC class or CD \\
Engine cooling system & Radiator \\
Engine dimension, length $\times$ width $\times$ height $(\mathrm{mm})$ & $607.5 \times 311.5 \times 469.0$ \\
\hline
\end{tabular}

The experiment was conducted in Sepuluh Nopember Institute of Technology combustion engine laboratory. The experiment utilized engine load within the range of $200-2000 \mathrm{~W}$ by an increment of $200 \mathrm{~W}$. The stages of testing are carried out by firstly inspecting the condition of readiness of the machine which includes the physical condition of the engine, lubricating, cooling system, fuel system and the readiness of the electric generator. Secondly, appraising the condition of loading system, electrical system and electrical connections that exist. Thirdly, inspecting the readiness of measuring tools and finally conducting an experiment to retrieve data.

The experiments were performed with the engine rotation fixed (stationary speed) with a variation of electrical load. The experiments begin by starting the diesel engine and heating the diesel engines $\pm 20 \mathrm{~min}$ at engine speed $1000 \mathrm{rpm}$ until the engine temperature reaches operating temperature. Afterward, the loads for the diesel engine are sets in a range from $200 \mathrm{~W}$ to $2000 \mathrm{~W}$ with $200 \mathrm{~W}$ increments. Lastly, recording the data needed for each load increase, such as $\Delta \mathrm{L}$ air manometer (to determine the mass flow rate of air required), time consumption of diesel oil per $10 \mathrm{ml}$, temperature incoming air, lubricating oil, coolant and exhaust gas, Voltage (V) and current (I). Once the data collection is completed, then the load is gradually lowered to zero load. The machine was left in no-load condition for about 5 minutes, and afterward turned off and idled for cool down.

\section{RESULTS AND DISCUSSION}

The density was examined using ASTM D-1298. The experimental result of density is shown in Figure 3. CMB reached $831 \mathrm{~kg} / \mathrm{m}^{3}$ of density, PPD reached $870 \mathrm{~kg} / \mathrm{m}^{3}$ of density and PBD reached $860 \mathrm{~kg} / \mathrm{m}^{3}$ of density. CMB has the lowest density value to 
the value of $831 \mathrm{~kg} / \mathrm{m}^{3}$, while PPD has the highest density value with the value of 870 $\mathrm{kg} / \mathrm{m}^{3}$.

Kinematic viscosity is a measure of the fluid resistance towards the weight of gravity. The kinematic viscosity was examined using ASTM D-445. The experimental result of kinematic viscosity is shown in Figure 4. The higher the viscosity, the fluid will be more viscous and difficult to flow. Whereas if the viscosity is too low then the fluid is flowing and gives less lubrication effect. From the data in Figure 4, it is discovered that $\mathrm{CMB}$ reached $2.7 \mathrm{cSt}$ of kinematic viscosity, PPD reached $3.5 \mathrm{cSt}$ of kinematic viscosity and PBD reached $3 \mathrm{cSt}$ of kinematic viscosity. CMB has the lowest viscosity value of 2.7 , while PPD has the highest viscosity value of 3.5 .

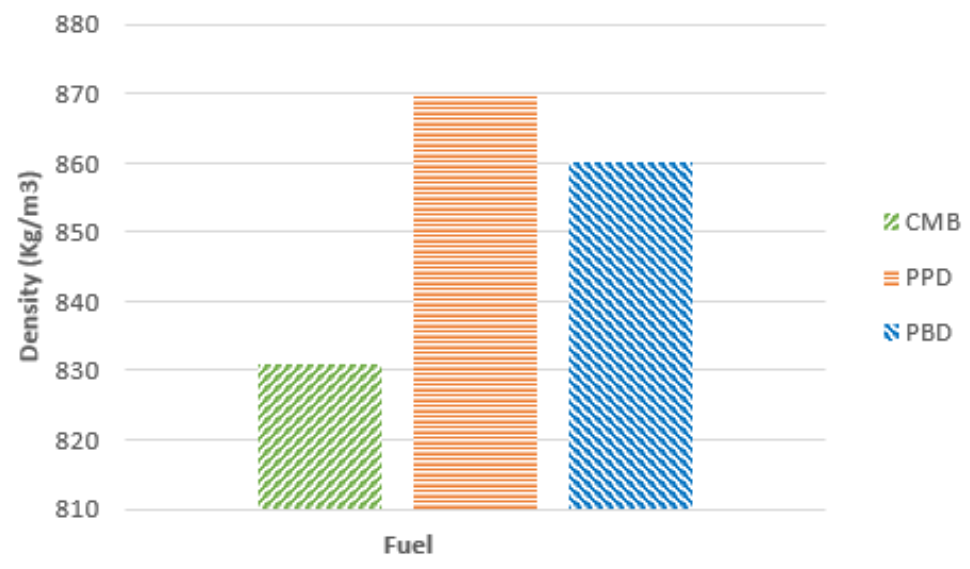

Figure 3. Density characteristic of various diesel fuel.

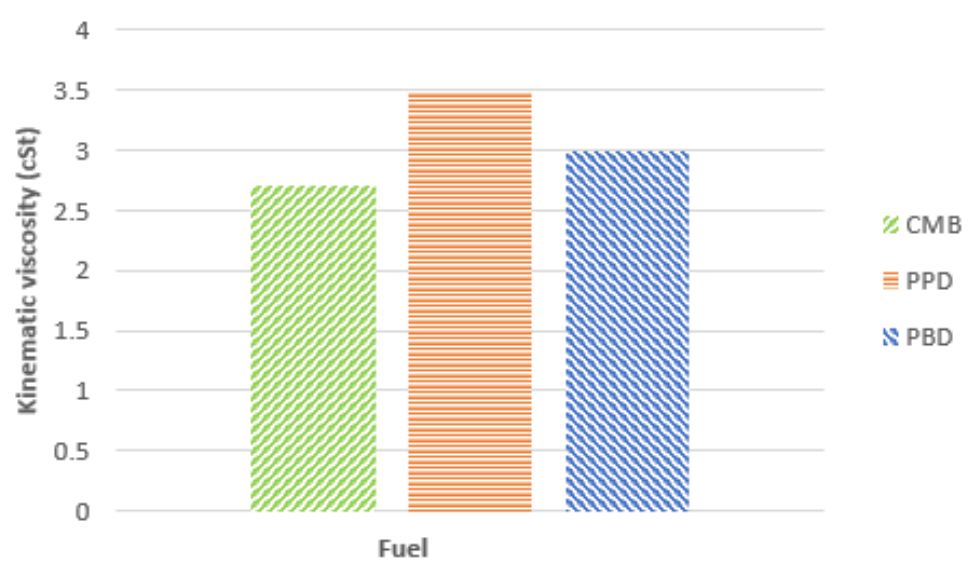

Figure 4. Kinematic viscosity characteristic of various diesel fuel.

Flash point is the lowest temperature at which a liquid can form an ignitable mixture in air near the surface of the liquid. The lower the flash point, the easier it is for the material to ignite. Flashpoint analysis has been examined through a laboratory test. The test was conducted using ASTM D-93. The experimental result of flash point is shown in Figure 5. CMB reached $69^{\circ} \mathrm{C}$ of flash point, PPD reached $60^{\circ} \mathrm{C}$ of flash point and PBD reached $52{ }^{\circ} \mathrm{C}$ of flash point. PBD has the lowest flash point value, whereas $\mathrm{CMB}$ has the highest flash point value. 
Pour point is a temperature where the fuel loses its flow characteristics. Pour point analysis has been examined through a laboratory test. The test used ASTM standardization of ASTM D-97. The experimental result of pour point is shown in Figure 6. CMB reached $18{ }^{\circ} \mathrm{C}$ of pour point, PPD reached $18^{\circ} \mathrm{C}$ of pour point, and PBD reached $18{ }^{\circ} \mathrm{C}$ of pour point. All the fuel has the same pour point value, which is $18{ }^{\circ} \mathrm{C}$.

There is always the sulfur content in petroleum-derived products. The excess of the sulfur content in petroleum derivative products can damage the machine because it is corrosive. Sulfur content analysis has been examined through a laboratory test. The test was conducted using ASTM D-4294. The experimental result of sulfur content is shown in Figure 7. CMB reached 0.05 wt.\% of sulfur content, PPD and PBD reached the same level of sulfur content as much as $0.35 \mathrm{wt} \% \mathrm{CMB}$ has the lowest sulfur content value with the value of 0.05 wt. $\%$, while PBD and PPD have the highest sulfur content value with a value of $0.35 \mathrm{wt} . \%$.

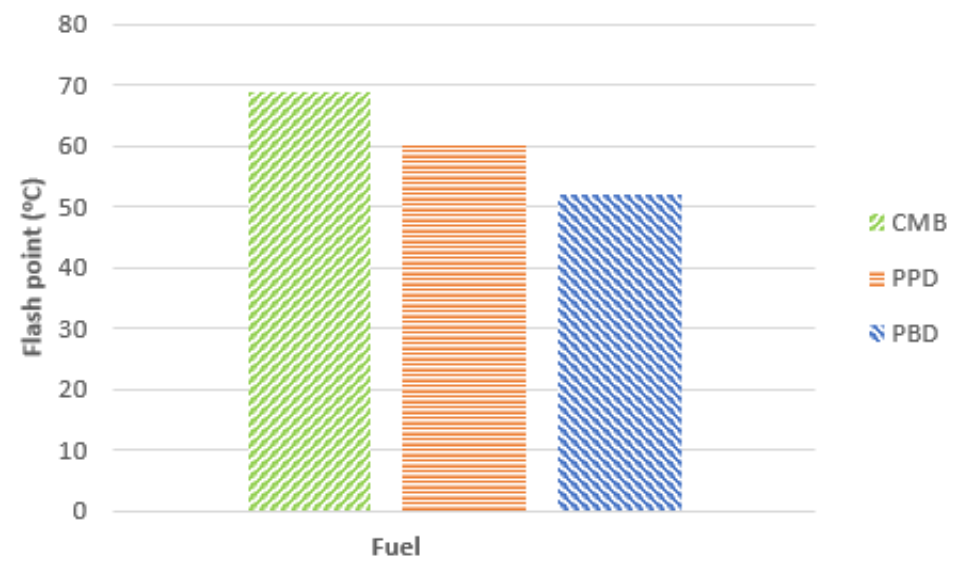

Figure 5. Flash point characteristic of various diesel fuel

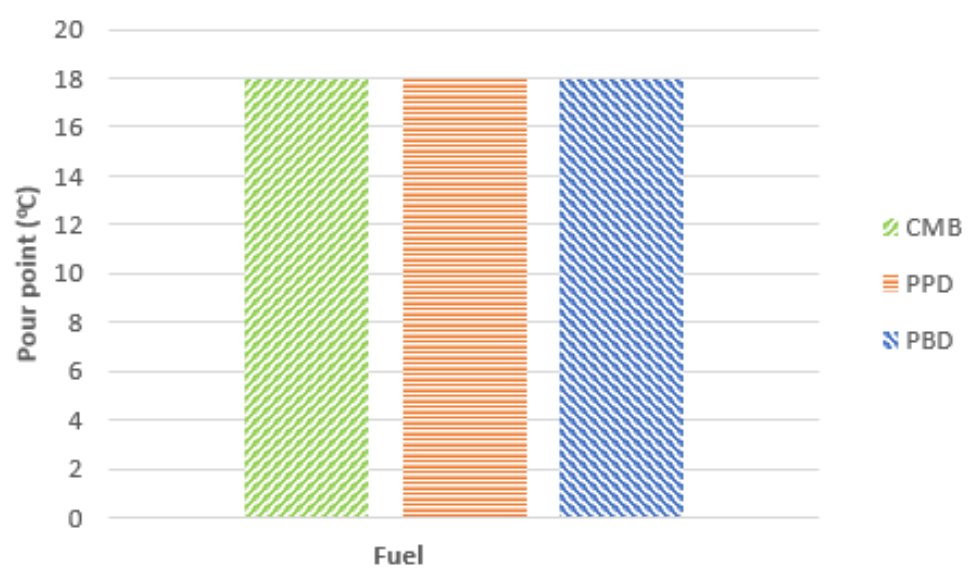

Figure 6. Pour point characteristic of various diesel fuel. 


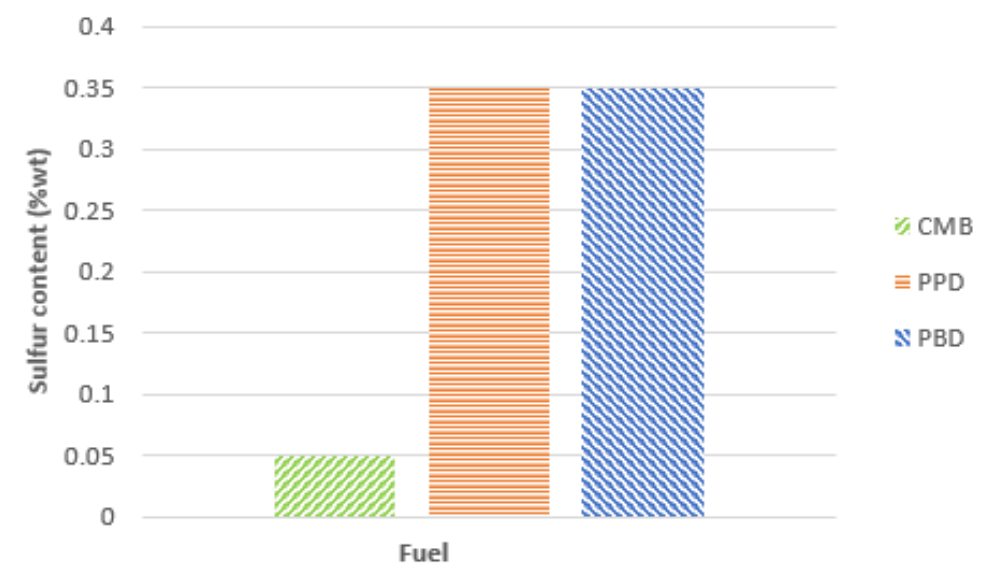

Figure 7. Sulfur characteristic of various diesel fuel.

Color analysis is a parameter to indicate the color level of the fuel. Color analysis has been examined through a laboratory test. The test used ASTM standardization of ASTM D-1500. The experimental result of the color is shown in Figure 8. It is discovered that PBD reached 3 points of color point, PPD and CMB reached the same 2.5 points of color point. PPD and CMB have the lowest color value with a value of 2.5, while PBD has the highest color value with a value of 3.0.

The water content is one parameter in determining the quality of a fuel, especially diesel fuel. This is because this parameter shows the water content in diesel fuel that may cause the fall of the temperature of the heat of combustion, resulting in foam and corrosive if it reacts with sulfur to form an acid. Water content has been examined through a laboratory test. The water content was examined using ASTM D6304. The experimental result of water content is shown in Figure 9. It is discovered that $\mathrm{CMB}$ reached $0.029 \mathrm{ppm}$ of water content, both PPD and PBD reached the same water content that is $0.05 \mathrm{ppm}$. CMB has a low water content value with the value of $0.029 \mathrm{ppm}$, while PBD and PPD have the highest water content value with a value of $0.05 \mathrm{ppm}$.

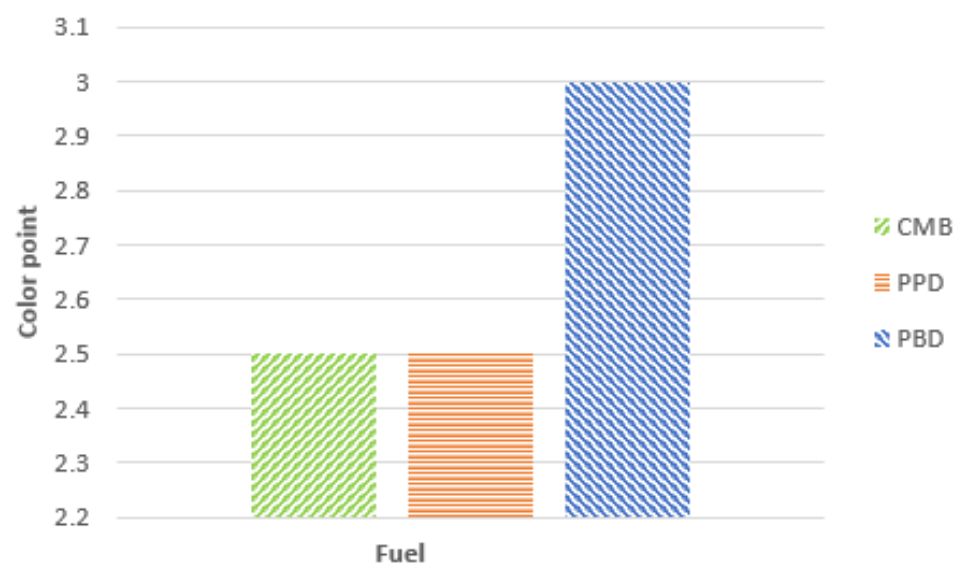

Figure 8. Color characteristic of various diesel fuel. 


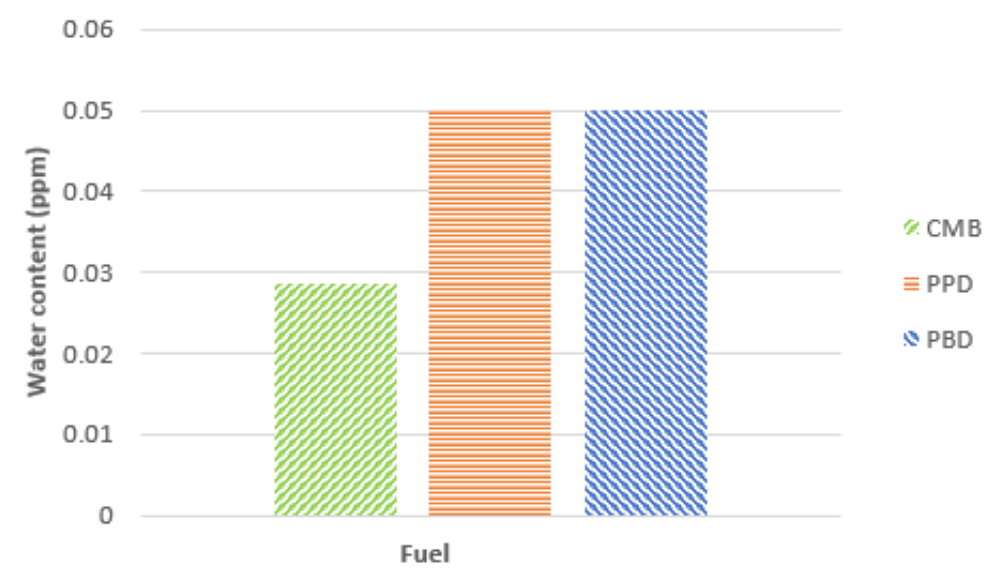

Figure 9. Water content characteristic of various diesel fuel

Cetane index is one of the quality guidelines of diesel fuel obtained from testing the properties of the fuel. The index is calculated based on volatility and the density of the fuel. Cetane index has been examined through a laboratory test. cetane index was examined using ASTM D-4737. The experimental result of cetane index is shown in Figure 10. it is discovered that PBD reached 47 points of cetane number, PPD reached 48 points of cetane number, and $\mathrm{CMB}$ reached 52 points of cetane number. $\mathrm{PBD}$ has the lowest cetane index value with the value of 47 , whereas $\mathrm{CMB}$ has the highest cetane index value with a value of 52 .

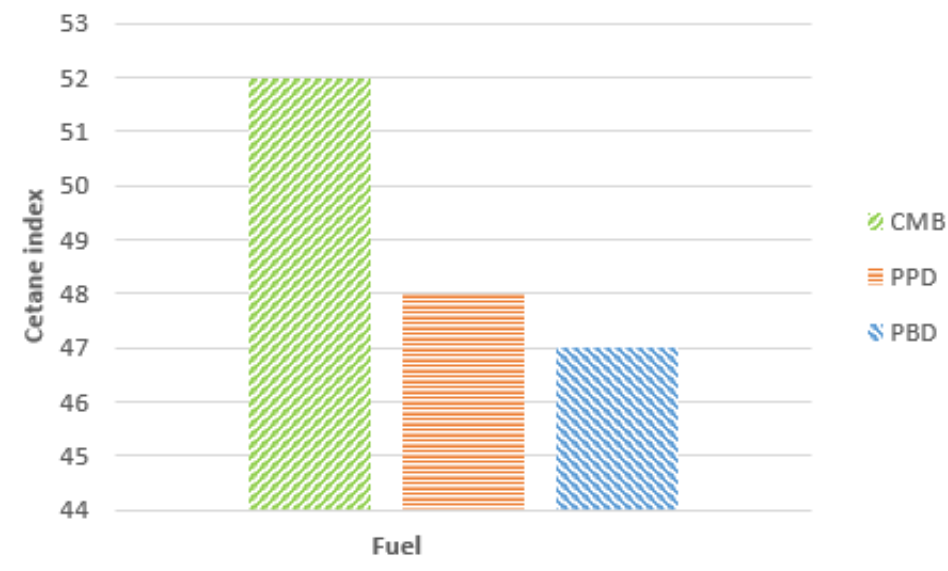

Figure 10. Cetane index characteristic of various diesel fuel.

Distillation is the process of separating the components or substances from a liquid mixture by selective boiling and condensation. Distillation (boiling) point of the fuel has been examined through a laboratory test. The distillation point was examined using ASTM D-86. The experimental result of distillation is shown in Figure 11. The distillation point of CMB is $334^{\circ} \mathrm{C}$, PPD and PBD have the same distillation point which is $370{ }^{\circ} \mathrm{C}$. The distillation point of $\mathrm{CMB}$ is the lowest with the value of $334{ }^{\circ} \mathrm{C}$, while the distillation point of PBD and PPD is the highest with the value of $370{ }^{\circ} \mathrm{C}$. The summary of these fuel characteristics result is given in Table 3. 


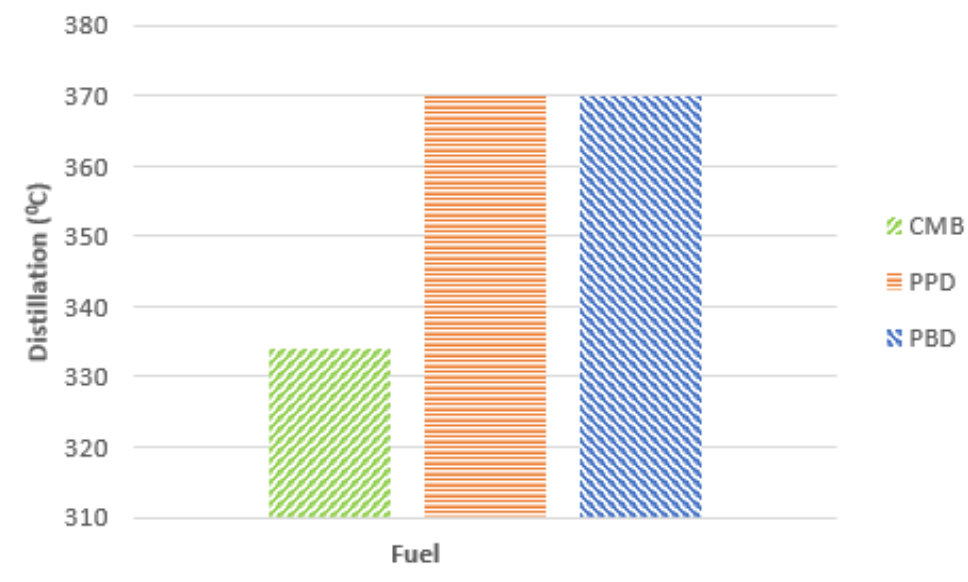

Figure 11. Variation of distillation point of various diesel fuel.

Table 3. Summary of fuel characteristics experimental result for Cerbera Manghas biodiesel (CMB), palm oil biodiesel (PPD) and pure petro-diesel (PBD).

\begin{tabular}{lccc}
\hline Fuel Characteristics & CMB & PPD & PBD \\
\hline Density $\left(\mathrm{kg} / \mathrm{m}^{3}\right)$ & 831 & 870 & 860 \\
Kinematic viscosity $(\mathrm{cSt})$ & 2.7 & 3.5 & 3 \\
Flash point $\left({ }^{\circ} \mathrm{C}\right)$ & 69 & 60 & 52 \\
Pour point $\left({ }^{\circ} \mathrm{C}\right)$ & 18 & 18 & 18 \\
Sulfur content $(\% \mathrm{wt})$ & 0.05 & 0.35 & 0.35 \\
Color point & 2.5 & 2.5 & 3 \\
Water content $(\mathrm{ppm})$ & 0.029 & 0.05 & 0.05 \\
Cetane index & 52 & 48 & 47 \\
Distillation $\left({ }^{\circ} \mathrm{C}\right)$ & 334 & 370 & 370 \\
\hline
\end{tabular}

Some of the parameters obtained from the diesel engine performance test results are: Power, Torque, the effective pressure for average braking (brake mean effective pressure, BMEP), specific fuel consumption (SFC), and thermal efficiency. A dynamometer was used to test the performance of the motor when using CMB, PPD, and PBD as fuel.

The parameter which exhibits the outcome of engine power is brake mean effective pressure (BMEP). Numerous values of BMEP with a variety of engine load are shown in Figure 12. From Figure 13, it can be concluded that BMEP value for CMB is higher compared to PPD and PBD. From the data presented in Figure 12, it is discovered that the BMEP from each fuel are as follows: PBD reached $388.77 \mathrm{kN} / \mathrm{m}^{2}$, CMB reached $414.98 \mathrm{kN} / \mathrm{m}^{2}$, and PPD reached $393.14 \mathrm{kN} / \mathrm{m}^{2}$. For the replacement of PPD with CMB, BMEP increased on average by $16.52 \%$ and for the replacement of PPD with PBD filling stations BMEP decreased on average by $5.68 \%$. 


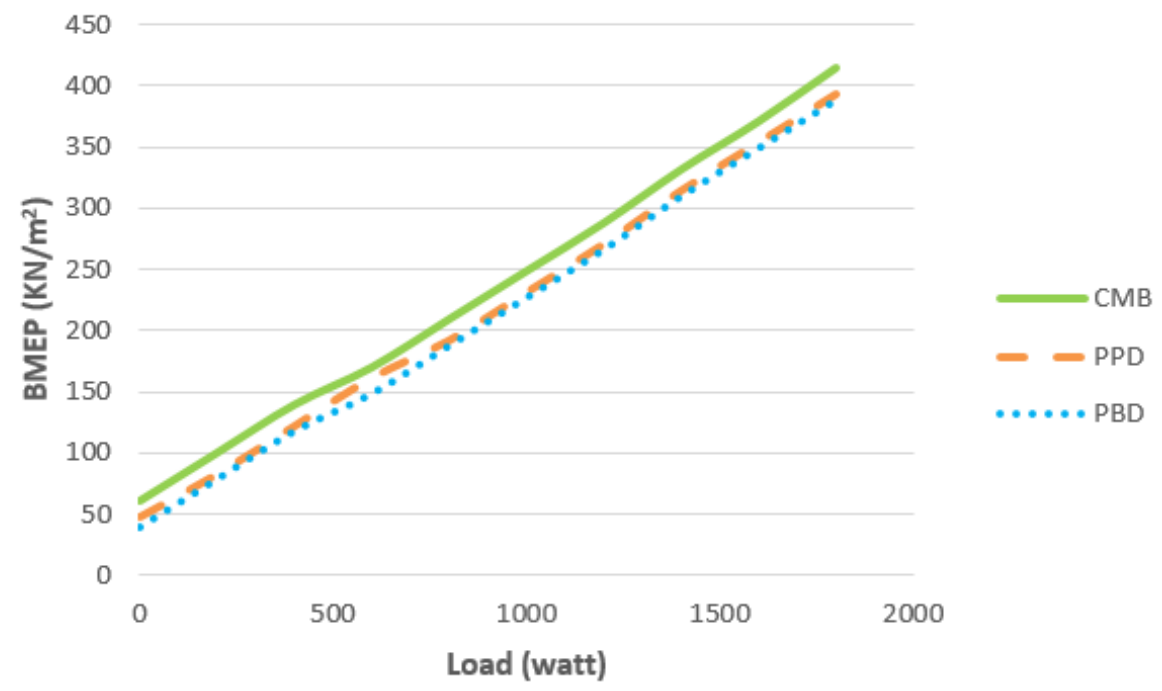

Figure 12. BMEP result of various diesel fuel.

The thermal efficiency of the engine is important in assessing the performance and economical value of an engine. The thermal efficiency can be raised by optimizing fuel properties and combustion system. Figure 13 shows blended CMB fuel has higher value than local PBD and PPD. From the data it is discovered that the thermal efficiency value from each fuel are as follows: PBD reached $21.23 \%$, CMB reached $23.05 \%$, and PPD reached $22.7 \%$. For the replacement of PPD with CMB increased thermal efficiency value by an average of $0.941 \%$ and for the replacement of PPD with PBD decreased thermal efficiency value by an average of $0.475 \%$.

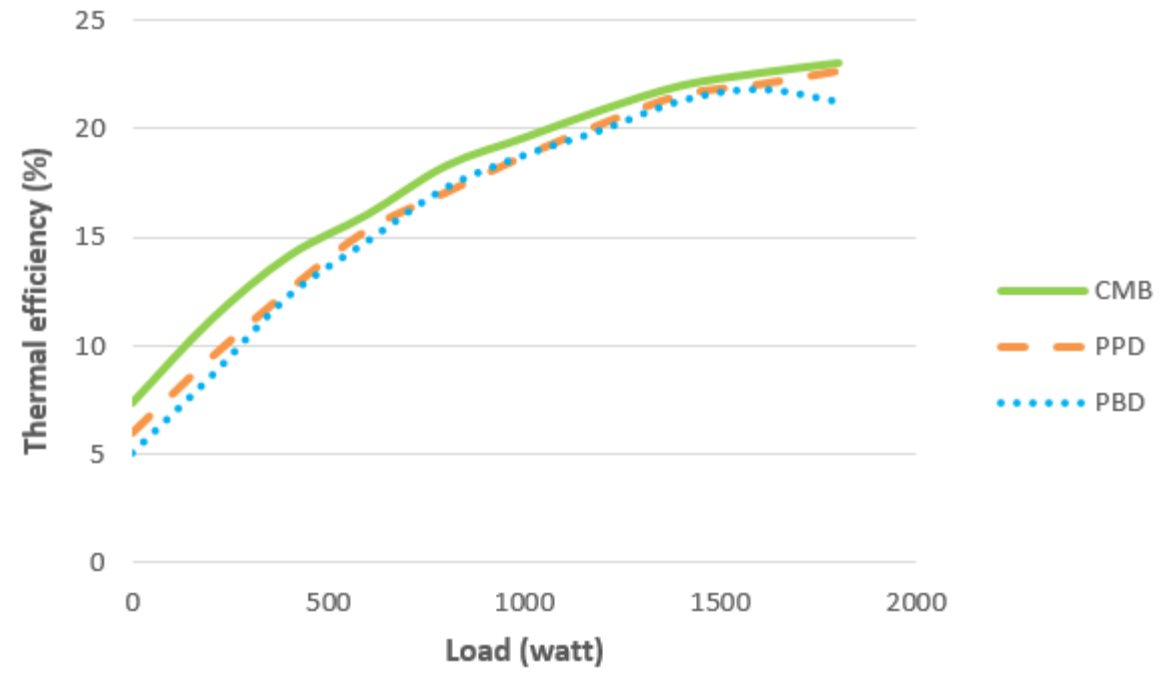

Figure 13. Thermal efficiency result of various diesel fuel

Specific fuel consumption (SFC) is the amount of fuel used to generate effective machine power for one hour. The specific fuel consumption with load for CMB volume fraction result is shown in Figure 14. From the data, it is discovered that SFC value from each fuel are as follows: PBD reached $0.4 \mathrm{~kg} / \mathrm{kW} . \mathrm{h}, \mathrm{CMB}$ reached $0.36 \mathrm{~kg} / \mathrm{kW} . \mathrm{h}$, and PPD reached $0.37 \mathrm{~kg} / \mathrm{kW}$.h. For the replacement of PPD with CMB, SFC decreased 
by an average of $0.058 \%$ and for the replacement of PPD with PBD, SFC increased by an average of $0.04 \%$.

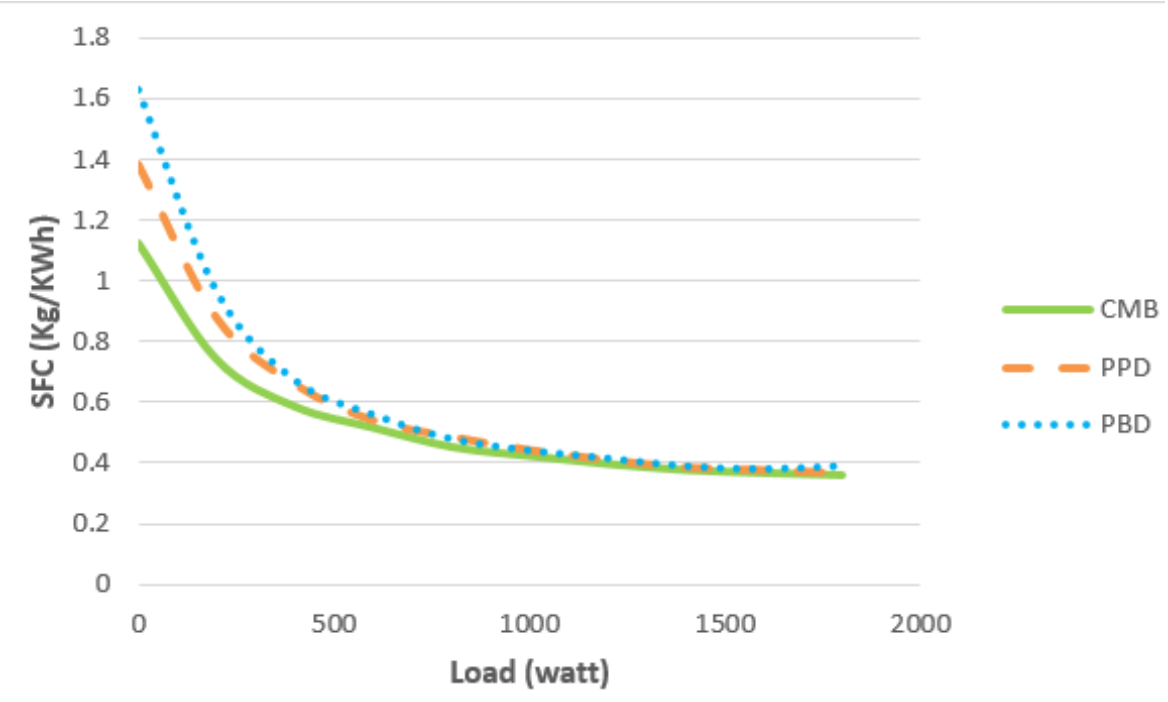

Figure 14. Specific fuel consumption result of various diesel fuel.

Torque is a measure of the ability of the engine to generate movement. Torque is the product of tangential force with arms that has the unit Nm (SI) or ft.lb (British). In practice, the torque of the engine useful to overcome obstacles while driving. The torque as a function of load result is shown in Figure 16. From the data, the torque value from each fuel are as follows: PBD reached $68.7 \mathrm{Nm}, \mathrm{CMB}$ reached $73.33 \mathrm{Nm}$, and PPD reached $69.47 \mathrm{Nm}$. For the replacement of PPD with CMB, torque increased by an average of $2.93 \%$ and for the replacement of PPD with PBD, torque decreased by an average of $1 \%$.

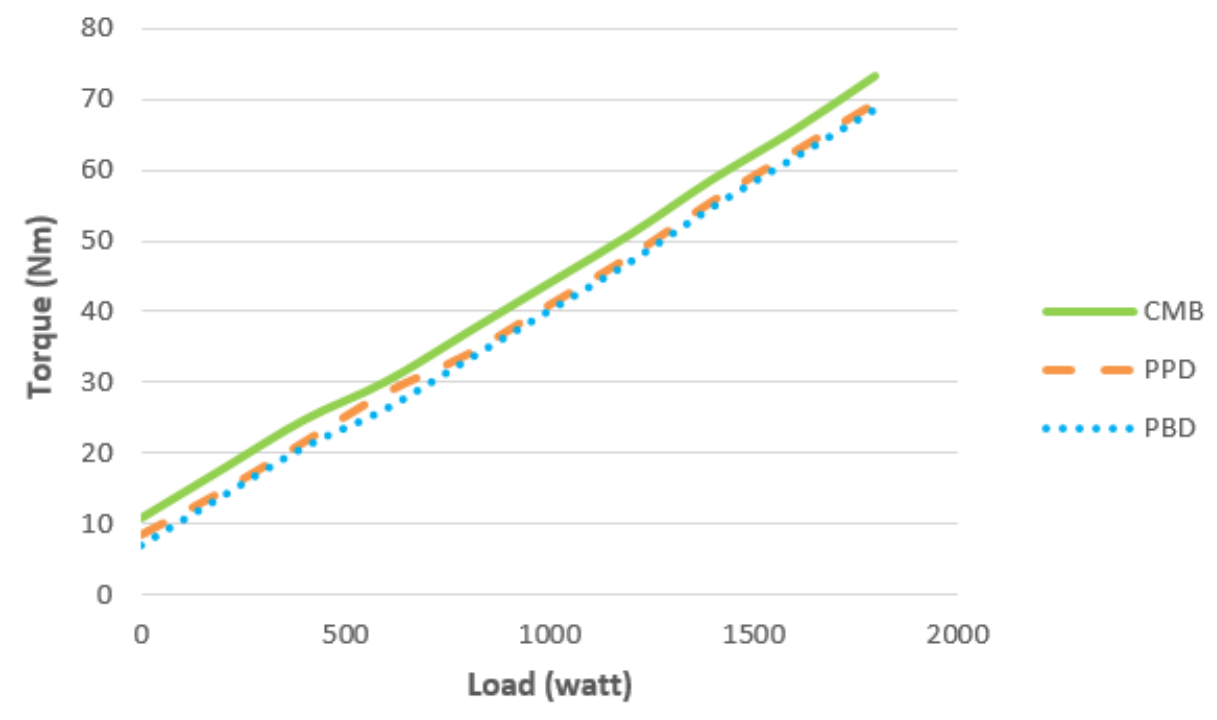

Figure 15. Torque result of various diesel fuel.

Engine power is the power supplied to cope with a given load. For a given measurement of the light load with a power of 200-2000 W. The power generated in 
diesel engine coupled with an electric generator can be calculated based on the load on the electric generator and declared effective on generator power $(\mathrm{Ne})$. The power as a function of load result is shown in Figure 16.

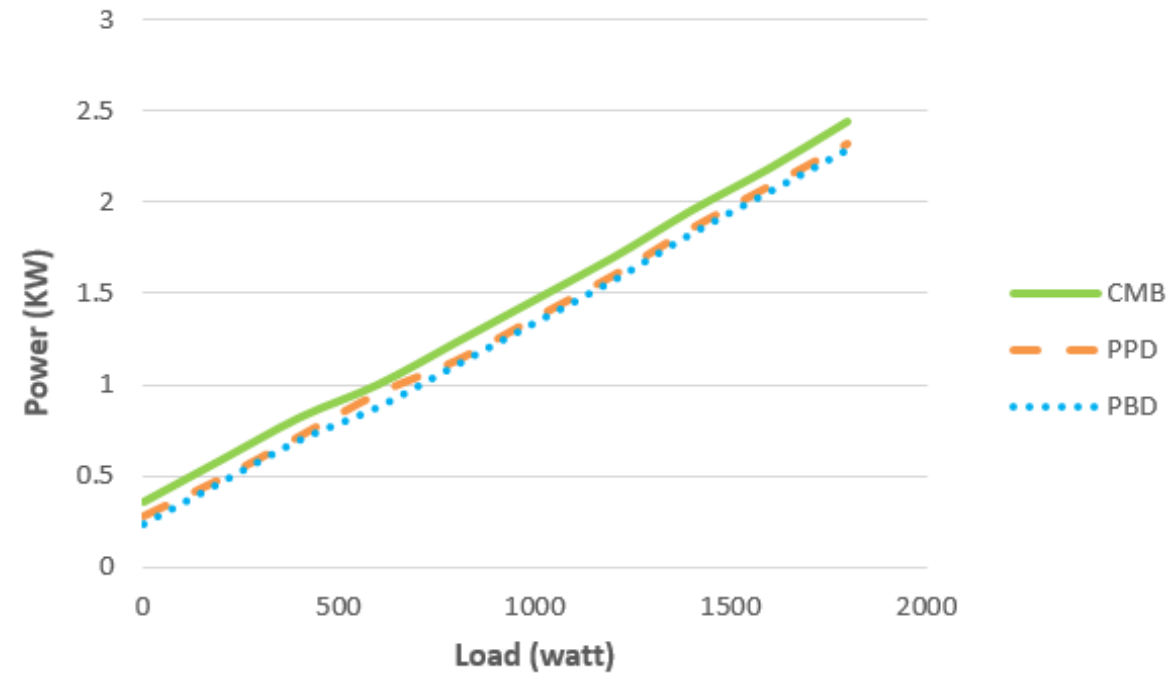

Figure 16. Power result of various diesel fuel.

From Figure 16, it is discovered that the power value of each fuel are as follows, PBD reached $2.3 \mathrm{~kW}, \mathrm{CMB}$ reached $2.44 \mathrm{~kW}$, and PPD filling stations reached 2.32 $\mathrm{kW}$. For the replacement of PPD with CMB power increased by an average of $0.097 \%$ and for the replacement of PPD with PBD, the power decreased by an average of 0.033 $\%$.

The results of engine performance tests are supported with the results of fuel properties investigation. The lower density and viscosity value in CMB resulted in less fuel flow problems and higher power [34]. The lower density value also leads to less specific fuel consumption [34]. The higher cetane index value in CMB compared to PPD and PBD leads to lower specific fuel consumption, higher torque, higher thermal efficiency and higher power [35,36]. As for water content, the lower water content in CMB causes increase in power, specific fuel consumption, and thermal efficiency [37].

\section{CONCLUSION}

The fuel characteristics investigation results indicate that Cerbera manghas biodiesel fuel has lower density, viscosity, sulfur content, color (lighter), water content, and distillation point when compared to pure petro-diesel and palm biodiesel. Cerbera manghas biodiesel fuel also has higher flash point and cetane index when compared to pure petro-diesel and palm biodiesel. Cerbera manghas biodiesel has the same pour point characterstic as pure petro-diesel and palm biodiesel.

It was found from engine experimental investigation that compared to pure petro-diesel fuel, Cerbera manghas biodiesel has $0.097 \%$ increase in power output, $2.93 \%$ increase in torque, $16.52 \%$ increase in BMEP, $0.058 \%$ decrease in SFC, and $0.941 \%$ increase in thermal efficiency. Compared to pure petro-diesel, palm biodiesel has $0.033 \%$ increase in power, $1 \%$ decrease in torque, $5.68 \%$ decrease in BMEP, $0.04 \%$ increase in SFC, and $0.475 \%$ decrease in thermal efficiency. This result shows that Cerbera manghas biodiesel engine performance test result is better than that of pure 
petro-diesel and palm biodiesel. The engine performance tests results are in line with fuel characteristics investigation. The lower density, specific fuel consumption, water content and higher cetane index in Cerbera manghas biodiesel give advantageous effect to the diesel engine performance.

\section{ACKNOWLEDGMENT}

Many thanks to Petra Christian University Indonesia and Direktorat Jendral Pendidikan Tinggi Kementerian Riset Teknologi Dan Pendidikan Tinggi Republik Indonesia (Hibah Penelitian Produk Terapan 2016-2017) which have supported this research.

\section{REFERENCES}

[1] Canakci M, Van Gerpen J. Biodiesel Production from Oil and Fats with high Free Fatty Acid. Trans. American Society of Agricultural Engineers 2001; 44(6): 1429-1436.

[2] Khalid A, Jaat N, Sapit A, Razali A, Manshoor A, Zaman I, Abdullah AA. Performance and Emissions Characteristics of Crude Jatropha Oil Biodiesel Blends in a Diesel Engine. International Journal of Automotive and mechanical Engineering (IJAME) 2015; 11: 2447-2457.

[3] Kumaran P, Gopinathan M, Kantharrajan S. Combustion Characteristics of Improved Biodiesel in Diffusion Burner. International Journal of Automotive and mechanical Engineering (IJAME) 2014; 10: 2112-2121.

[4] Anggono W, Sutrisno, Suprianto FD, Evander J. Biomass Briquette Investigation from Pterocarpus Indicus Leaves Waste as an Alternative Renewable Energy. IOP Conference Series: Material Science and Engineering 2017; 241: 012043.

[5] Rostami S, Ghobadian B, Kiani Deh Kiani M. Effect of The Injection Timing on the Performance of a Diesel Engine Using Diesel-Biodiesel Blends. International Journal of Automotive and mechanical Engineering (IJAME) 2014; 10: 1945-1958.

[6] Azad A.K, Rasul M.G, Giannangelo B, Islam R. Comparative Study of Diesel Engine Performance and Emission with Soybean and Waste Oil Biodiesel Fuels. International Journal of Automotive and mechanical Engineering (IJAME) 2015; 12: 2866-2881.

[7] Hariram V, Mohan Kumar G. Combustion Analysis of Algal Oil Methyl Ester in a Direct Injection Compression Ignition Engine. Journal of Engineering Science and Technology 2013; 8(1): 77-92.

[8] Sutrisno, Anggono W, Suprianto FD, Kasrun AW, Siahaan IH. The Effects of Particle Size and Pressureon The Combustion Characteristics of Cerbera Manghasleaf Briquettes. ARPN Journal of Engineering and Applied Sciences 2017; 12(4): 931-936.

[9] Anggono W, Suprianto FD, Sutrisno, Gotama GJ, Evander J, Kasrun AW. Investigation on Biomass Briquette from Cerbera Manghas Waste Twigs as Renewable Energy Source. ARPN Journal of Engineering and Applied Sciences 2018; 13(3): 1080-1084.

[10] Demirbas A. Progress and recent trends in biodiesel fuels. Energy Conversion and Management 2009; 50(1):14-34. 
[11] Azhari Mohd Ghazi TI, Gunam Resul MFM, Yunus R, Shean Yaw TC. Preliminary Design of Oscillatory Flow Biodiesel Reactor for Continuous Biodiesel Production from Jatropha Triglycerides. Journal of Engineering Science and Technology 2008; 3(2): 138-145.

[12] Ho KC, Shahbaz K, Rashmi W, Mjalli FS, Hashim MA, Alnashef IM. Removal of Glycerol from Palm Oil-Based Biodiesel Using New Ionic Liquids Analogues. Journal of Engineering Science and Technology 2015; EURECA 2014 Special Issue January: 98-111.

[13] Silitonga AS, Atabani AE, Mahlia TMI, Masjuki HH, Badruddin IA, Mekhilef S. A review on Prospect of Jatropha Curcas for Biodiesel in Indonesia. Renewable and Sustainable Energy Reviews 2011; 15: 3733-3756.

[14] Talha NS, Sulaiman S. Overview of Catalyst in Biodiesel Production. ARPN Journal of Engineering and Applied Sciences, 2016; 11(1): 439-448.

[15] Ramaraju A, Ashok Kumar TV. Biodiesel Development from High Free Fatty Acid Punnakka Oil. ARPN Journal of Engineering and Applied Sciences, 2011; 6(4): 1-6.

[16] Bojan SG, Chelladurai S, Durairaj SK. Batch Type Synthesis of High Free Fatty Acid Jatropha Curcus Oil Biodiesel- India as Supplying Country. ARPN Journal of Engineering and Applied Sciences, 2011; 6(8): 73-78.

[17] Salvi BL, Panwar N. Biodiesel Resources and Production Technologies - A Review. Renewable and Sustainable Energy Reviews, 2012. 16: 3680-3689.

[18] Sarin R, Sharma M, Sinharay S, Malhotra RK. Jatropha-Palm Biodiesel Blends: An optimum mix for Asia. Fuel, 2007; 86: 1365-1371.

[19] Azad AK, Ameer Uddin SM, Alam MM. A Comprehensive Study of Diesel Engine Performance With Vegetable Oil: An Alternative Bio-Fuel Source of Energy. International Journal of Automotive and mechanical Engineering (IJAME) 2012; 5: 576-586.

[20] Ikwuagwu O, Ononogbu IC, Njoku OU. Production of biodiesel using rubber [Hevea brasiliensis (Kunth. Muell.)] seed oil. Industrial Crops and Products 2000; 12(1): 57-62.

[21] Demirbas A. Relationships derived from physical properties of vegetable oil and biodiesel fuels. Fuel 2008; 87: 1743-1748.

[22] Singh SP, Singh D. Biodiesel production through the use of different sources and characterization of oil sand their esters as the substitute of diesel: a review. Renewable and Sustainable Energy Reviews 2010; 14: 200-216.

[23] Yaakob Z, Mohammad M, Alherbawi M, Alam Z, Sopian K. Overview of the production of biodiesel from waste cooking oil. Renewable and Sustainable Energy Reviews 2013; 18: 184-93.

[24] Benjumea P, Agudelo J, Agudelo A. Basic properties of palm oil biodieseldiesel blends. Fuel 2008; 87: 2069-2075.

[25] Chen YH, Chen JH, Chang CY, Chang CC. Biodiesel production from tung (Vernicia montana) oil and its blending properties in different fatty acid compositions. Bio resource Technology 2010; 101: 9521-9526.

[26] Said NH, Ani FN, Said MFM. Review of The Production of Biodiesel from Waste Cooking Oil Using Solid Catalysts. Journal of Mechanical Engineering and Sciences 2015; 8: 1302-1311.

[27] Borugadda VB, Goud VV. Biodiesel Production from Renewable Feedstocks: Status and Opportunities. Renewable and Sustainable Energy Reviews 2012; 16: 4763-4784. 
[28] Atabani AE, Silitonga AS, Ong HC, Mahlia TMI, Masjuki HH, Badruddin IA, Fayaz H. Non-Edible Vegetable Oils: A Critical Evaluation of Oil Extraction, Fatty Acid Compositions, Biodiesel Production, Characteristics, Engine Performance and Emissions Production. Renewable and Sustainable Energy Reviews 2013; 18: 211-245.

[29] Yu H, Zhang L, Zheng C, Guo L, Li W, Sun P, Qin L. Recent Developments and Future Prospects of Antimicrobial Metabolites Produced by Endophytes. Microbiological Research 2010; 165: 437-449.

[30] Monjur-Al-Hossain ASM, Sarkar S, Saha S, Lokman Hossain Md, Mahadhi Hasan Md. Biological assessment on Cerbera manghas (linn.). Pharmacology Online Archives 2013; 1: 155-160.

[31] Ong HC, Silitonga AS, Mahlia TMI, Masjuki HH, Chong WT. Investigation of Biodiesel Production from Cerbera manghas Biofuel Resources. Energy Procedia 2014; 61: 436-439.

[32] Zhang XP, Pei YH, Liu MS, Kang SL, Zhang JQ. Chemical constituents from the leaves of Cerbera manghas. Asian Pacific Journal of Tropical Medicine 2010; 109-111.

[33] Severson E, Jufer-Phipps R, Fowler D.R, Alexander R. Beyond the Boundaries of Forensic Toxicology - The Use of an Atypical Consultant in a Rare Case of Cerberin Poisoning. Acad Forensic Pathol 2015; 5(1): 140-144.

[34] Utlu Z, Kocak MS. The Effect of Biodiesel Fuel Obtained from Waste Frying Oil on Direct Injection Diesel Engine Performance and Exhaust Emissions. Renewable Energy 2008; 33: 1936-1941.

[35] Yakup Icingur, Duran Altiparmak. Effect of Fuel Cetane Number and Injection Pressure on a DI Diesel Engine Performance and Emissions. Energy Conversion and Management 2003; 44: 389-397.

[36] Ahmed ST, Chaichan MT. Effect of Fuel Cetane Number on Multi-Cylinders Direct Injection Diesel Engine Performance and Exhaust Emissions. AlKhwarizmi Engineering Journal 2012; 8(1): 65-75.

[37] Awad OI, Mamat R, Noor MM, Yusop F, Yusri IM. The Impacts of Moisture Content on Performance and Emissions of a Four-Cylinder SI Engine Running with Fuse Oil-Gasoline Blends. WSEAS Transactions on Environment and Development 2017; 13: 120 - 128. 